\title{
Research on the Development Direction of International Commercial Arbitration Network
}

\author{
Yalong An \\ Beijing Technology and Business University, Beijing, China \\ Email: anyalong008@163.com
}

How to cite this paper: An, Y. L. (2021). Research on the Development Direction of International Commercial Arbitration Network. Beijing Law Review, 12, 914-923. https://doi.org/10.4236/blr.2021.123047

Received: August 17, 2021

Accepted: September 15, 2021

Published: September 18, 2021

Copyright $\odot 2021$ by author(s) and Scientific Research Publishing Inc. This work is licensed under the Creative Commons Attribution International License (CC BY 4.0).

http://creativecommons.org/licenses/by/4.0/

\begin{abstract}
With the advancement and popularization of computer technology, arbitration methods and they are also developing in the direction of low cost and high efficiency. Nowadays, alternative methods to traditional dispute settlement methods have gradually emerged on the Internet, and network arbitration has emerged with the trend of the times. Due to its convenience and efficiency, network arbitration has received extensive attention since its birth. However, due to a series of its own reasons, network arbitration has also been left out to a certain extent. In order to further explore and analyze the development prospects and influencing factors of network arbitration, this article elaborates and analyzes the development status of network arbitration. This article mainly adopts the literature research method and the comparative analysis method, that is, according to the content of the network arbitration to be studied, sufficient information can be obtained by consulting the relevant literature, so as to fully understand the background, history, current situation and prospects of the network arbitration. After collecting and analyzing theories, systematically analyze them based on the existing research results, and compare them with the previous related documents, summarize the areas that need improvement, and further improve the theory so that the theory is well-founded and the design is more reasonable, and finally expresses some of my thoughts on the future development of network arbitration.
\end{abstract}

\section{Keywords}

Internal and External Factors, Assumptions, Determination of the Place of Arbitration

\section{Introduction}

On June 17, 2021, the Supreme People's Court held a press conference to release 
the "People's Court Online Litigation Rules", which is also the first judicial interpretation to guide the national courts to carry out online litigation work (Zheng, 2021).

Now that we have entered the Internet age, the traditional trial process has shifted from offline to online, and data and information have been shifted from paper to cloud operations. Significant changes have taken place in litigation links such as case filing, service, mediation, court trial, evidence production, and cross-examination (Ming \& Sun, 2021). The established trial model procedures, online litigation procedures, and substantive judgment rules that are compatible with the Internet age constitute the Internet justice organically.

In May 2016, my country's first Internet court was established in Beijing. “The Internet Arbitration Court of Qingdao Arbitration Commission” was officially inaugurated in Beijing. This is China's first Internet court (China Lawyers Association Website, 2016).

Undoubtedly, my country's Internet justice, also known as online justice, is already ahead of the Internet courts in the world (Zhu, 2004). In the course of operation, many problems in judicial procedures have been solved and great achievements have been made. In the field of international arbitration, "Internet arbitration" is also an emerging force in the field of international civil and commercial procedural law (Liu \& Chen, 2004). The origin of Internet arbitration is not the Internet. It is the product of the development of traditional arbitration in the Internet age. Therefore, it must have an inseparable connection with traditional arbitration (IBA Ethics for International Arbitrators, 1987).

Nowadays, there are many factors hindering the development of network arbitration. This paper will list the relevant factors and doubts that limit the development of network arbitration, and further analyze the methods of liberation, and propose ideas for the future development of network arbitration.

\section{Internal and External Factors Hindering the Development of Online Arbitration}

The innovation of online arbitration as a civil dispute resolution method lies in the media. Its method is roughly the same as the traditional arbitration method. It only uses the Internet channel as the medium to transfer the place of arbitration from the arbitration tribunal to the Internet. At present, there are divergent opinions on the definition of online arbitration in the international community. Online arbitration is generally understood to mean that all links of arbitration are conducted on the Internet in strict accordance with the characteristics of "online" arbitration (Mordi, 2016). As far as the actual situation is concerned, due to the limitations of network technology and legal system protection, it is unrealistic to realize the entire arbitration process through the network (Kamanga, 2021). Therefore, the use of full-process online arbitration for dispute resolution is still somewhat ideal, and some procedures that cannot be arbitrated through the Internet still require traditional arbitration methods (ICC). This has also 
caused the slow development of online international commercial arbitration. At its root, it is necessary to analyze its internal and external causes.

Internal reasons, because online arbitration depends on the development of network technology. Technology in the field of international commercial arbitration mainly refers to information technology. We must admit that the development of information technology at this stage is still one of the main constraints on the development of network arbitration, such as network technology problems (Margulead Ltd v. Exide Technologies, 2005). This problem may be alleviated after the general implementation of $5 \mathrm{G}$ technology in China. How to build the necessary system procedures reasonably is also a problem that needs to be faced in the development of network arbitration. I think the network arbitration system can be maximized (Metal Distributors, 2009). Built as a comprehensive system, the problem of integrating audio, image, identity authentication, electronic signature, data management and other network communication technologies into an innovative arbitration application system will be solved to a large extent in the development of future technology.

Therefore, I believe that the main reason is not internal reasons, but at the level of the legal system, especially in the legislative and judicial aspects, that is, external reasons.

First, the legal validity of online arbitration has been questioned. At present, my country's legislation does not have clear provisions on the legal effect of online commercial arbitration, which leads to uncertainty in the legal effect of online commercial arbitration. For example, in practice, there are situations in which online commercial arbitration awards are not recognized or enforced by the courts (Park, 2012). If online arbitration is to win the recognition of my country's legislation, the best solution is to obtain the recognition of my country's "Arbitration Law" for the network arbitration business.

Second, the psychological factors of the masses. The influence of psychological factors refers to the degree of people's acceptance of online arbitration, which is related to the possibility of the parties choosing online arbitration (Porter v. Magill, 2001).

For the parties, resolving disputes, clarifying rights and obligations, and finally implementing them is the most important thing. People generally guarantee the authenticity and fairness of the arbitration results (Primetrade AG v. Ythan Ltd, 2006). The authenticity of arbitration involves matters that affect the fairness of arbitration mainly including: the identity of the parties Confirmation, display of original evidence, and confirmation of arbitration results (Redfern et al., 2015).

\begin{tabular}{ll}
\hline \multicolumn{1}{c}{ Internal factors } & \multicolumn{1}{c}{ External factors } \\
$\begin{array}{ll}\text { 1. The development of information technology is } \\
\text { not complete }\end{array}$ & $\begin{array}{l}\text { 1. The legal effect of network arbitration has } \\
\text { been questioned }\end{array}$ \\
$\begin{array}{ll}\text { 2. Network technology needs to be improved } & \text { 2. The psychological factors of the masses }\end{array}$
\end{tabular}




\subsection{Identity Confirmation}

The identity confirmation can be guaranteed by the arbitration institution, that is, it is determined that the arbitrator has the relevant arbitration qualifications, but the identity confirmation of the parties is risky (Rio Algom Inc. v. Sammi Steel Co., 1991). If the unfavorable party in the dispute may deliberately adopt the method of "putting the crown and wearing the crown", and later use the untrue identity to avoid disadvantages (IBA Guidelines, 2004). I think that after the parties submit the arbitration application, the parties can be allowed to perform a unique electronic signature. After the signature is completed, an electronic signature file can be obtained as a proof of identity confirmation in the future, which cannot be lost and the parties should be notified in advance.

\subsection{Display of Original Evidence}

Evidence in online arbitration will mostly be electronic evidence documents, and the authenticity of electronic evidence is indeed a controversial issue in online arbitration (ICC Case No. 1776). The parties cannot examine and cross-examine the evidence face to face. The arbitrator loses the opportunity to observe the parties' conversations, directly ask the parties' questions, and learn about their physical or emotional information (Margulead Ltd v. Exide Technologies, 2005). All these difficult things can affect the arbitrator's judgment on the "trustworthiness" of the parties. In order to solve this problem, part of the evidence can be exchanged through pre-trial evidence to ensure the authenticity of the evidence, and the other part needs to be resolved with the help of intermediary agencies such as notary agencies and appraisal agencies (Akinbote, 2009). Through the exchange of evidence before the court, the parties can filter out the evidence suspected of authenticity and deal with it separately; when necessary, the authenticity can be confirmed by the notary office (Alfred Topper Inc., 1965).

\subsection{Confirmation of Arbitration Results}

The confirmation of the arbitration result can be formed through the traditional paper version to ensure the fairness and authoritative judgment of the court's execution and ruling, and to make the public more convinced (Arbitration Act, 1996).

\section{Determination of the Place of Arbitration}

A big problem with the external factors hindering the development of online arbitration is the determination of the place of arbitration.

The place of arbitration refers to the place where the arbitration proceeding or the place where the arbitration takes place. In traditional international commercial arbitration, the place of arbitration is an indispensable and important factor (Arbitration and Conciliation Act s.5., 1996).

From filing an application, submitting relevant materials, to starting the trial to making a ruling on the case, the entire arbitration process needs to be con- 
ducted in a specific place.

Compared with traditional arbitration, due to the virtual nature of the network, online arbitration makes it difficult to determine the place of arbitration (Berg, 1981). There is no physical arbitration place similar to traditional arbitration, and there is a "missing" of the place of arbitration.

However, the determination of the place of arbitration is closely related to the procedural law applicable to arbitration and the substantive law of which country's conflict rules are used to determine the contract (Dallah Real Estate \& Touris Holding Co v Pakistan, 2010). It is also related to the validity of the arbitration agreement and the determination of the nationality of the arbitration award, and affects whether the award can be determined.

It is recognized and enforced, so it is of great significance to determine the place of arbitration for online arbitration.

At present, with the exception of a few arbitration institutions, there is no clear and systematic regulation on the issue of online arbitration in the relevant international laws and regulations and the internal laws of various countries (Carob Industries Pty Ltd., 2000). There is no more rigorous and easy-to-operate regulation on how to determine the place of arbitration for online arbitration.

Method. Many scholars have also tried to put forward many definite methods regarding the lack of online arbitration venues.

In summary, the mainstream views are mainly as follows:

\subsection{Doctrine of the Location of the Arbitrator}

Scholars who support this doctrine believe that the place of arbitration for online arbitration should be determined based on the location of the arbitrator or chief arbitrator.

It can be understood that when the arbitration tribunal is sole, then the location of the sole arbitrator is the place of arbitration for online civil and commercial arbitration; and when the arbitration tribunal is composed of more than 3 persons, that is, it is a collegiate panel, then the presiding arbitrator. The location of the member is the place of arbitration on the Internet (Chuprunov, 2012). This view seems reasonable but has many flaws. First of all, the doctrine does not clearly indicate the "location" of the arbitrator or presiding arbitrator's domicile, habitual residence, or nationality Secondly, it does not clarify when the location is counted, whether it is at the beginning of the procedure or when the award is issued? Furthermore, the doctrine does not take into account the possible mobility of arbitrators, such as travel and relocation.

Therefore, it is obviously unscientific to use such a "location" as the place of arbitration, which is not unique, stable and predictable.

\subsection{The Location of the Web Server}

Scholars who hold this view believe that the place of arbitration is determined based on the location of the web server used in the online arbitration procedure, 
that is, the location of the physical space of the web server is used as the place of online arbitration.

The shortcomings of this view are also obvious.

First of all, the parties involved in online arbitration, arbitrators and other participants may be located in different locations, different countries or regions. In this way, the entire arbitration process requires several web servers in several locations (Cooke, 2000). It is difficult to find out where all the servers are.

Secondly, since the entire arbitration procedure may have to go through multiple servers, using this kind of service provided by multiple network service providers will have multiple network server locations, and it is still difficult to determine the place of arbitration.

Finally, the specific server used by all parties involved in the arbitration procedure is not fixed, and there will be great chances, many of which are random (Dow Chemical France, 1984). Obviously, this view is also unreasonable.

\subsection{Non-Domestic Arbitration Theory}

This theory is also called delocalized arbitration theory and floating arbitration theory. The basic content is: arbitration is independent and not restricted by the law of the country where the place of arbitration is located; the arbitration award has no nationality, and its legal effect does not need to be conferred by the law of the country where the place of arbitration is located. The autonomy of the parties is its own.

Source of validity: Before applying for enforcement, an arbitration award is not subject to the supervision of any national court, and no country's court has the right to revoke the award. The only way to supervise arbitration is not to enforce it (Gaillard \& Savage, 1999); if the arbitration award does not violate international public policy, then the enforcement effect of the ruling should be recognized by all countries.

Article 18 of the Arbitration Rules of the United Nations Commission on International Trade Law (revised in 2010) stipulates that "If the parties have not agreed on the place of arbitration in advance, the arbitration tribunal shall determine the place of arbitration based on the facts of the case. The award shall be deemed to have been made at the place of arbitration. Deliberations shall be held at any place it deems appropriate (Hanotiau, 2006). Unless the parties agree otherwise, the arbitral tribunal may also hold meetings for any other purpose at any place it deems appropriate, including holding hearings".

In summary, the main content of non-domestic arbitration theory is:

First, the arbitration procedure is not restricted by the national law of the place of arbitration, and can be conducted in accordance with the agreement of the parties or the arbitration rules. The arbitration can be conducted in any place.

Second, the validity of the arbitration award cannot be determined based on the national law of the place of arbitration. The enforcement effect of the award 
will not be affected by the court where it is made. The country where the award is enforced can apply for enforcement of the award.

Third, non-enforcement of arbitration awards is the only way to supervise arbitration.

In addition to the "public policy" reservation, the court of the country where the application is applied for enforcement must recognize and enforce the arbitration award.

Although the theory of "non-domestic arbitration" is very suitable for online arbitration, the theory itself has certain flaws.

To allow online international commercial arbitration to be completely free from domestic arbitration laws, but to be autonomous based on the will of the parties. It is impossible to fully realize in real life, and not everyone is conscious.

The court of the arbitration country participates in the entire process of online international commercial arbitration. Non-domestic arbitration theory only applies to the law of the place where the arbitration is performed, and excludes the constraints and judicial supervision of other laws. Non-domestic arbitration theory is too idealistic. According to the non-domestic arbitration theory, based on the autonomy of the parties' will, the arbitration award is always binding once it is made. According to the agreement reached between the parties, the parties will automatically perform their obligations and enforce the award. The parties will abide by the arbitration agreement and the award. This idea is too idealistic.

\subsection{Other Theories}

1) Some scholars advocate the location of the arbitrator, and believe that the place of arbitration for online arbitration should be determined based on the location of the arbitrator or the presiding arbitrator. The arbitration is deemed to be conducted at the location of the arbitrator or the presiding arbitrator, but the location is the place of residence and customary. Is the place of residence or the actual location during the arbitration proceedings? It is uncertain, so that the parties cannot foresee the legal system under which the ruling will be made.

2) Some scholars advocate the server location theory, and believe that the physical space of the network server that enables online arbitration is the place of arbitration for online arbitration, but the entire arbitration process involves multiple servers, and the location of these servers is random. And contingency, there is no obvious connection with parties or substantive transactions, so this method is unreasonable.

3) Some scholars advocate the theory of the location of the website owner or controller, and believe that the place of arbitration for online arbitration should be the location of the website owner or controller. Because the owner of the domain name as the external code of the website's IP address is specific, it is easy to verify the owner or controller of the website, but there is no necessary identity between the owner and the controller of the website. 
4) Some scholars advocate the theory of the location of online arbitration institutions. This theory may allow the country where the arbitration institution is located to use the "court inconvenience principle" not to exercise jurisdiction over arbitration.

\section{Situation on the Recognition and Enforcement Mechanism of Network Arbitration Awards}

The determination of the place of network arbitration will affect the recognition of the network arbitration award and the related implementation. There are two different ways in the current judicial practice regarding the recognition and enforcement of online commercial arbitration awards: the adoption of the offline recognition and enforcement system of arbitration awards, and the autonomous recognition and enforcement of online arbitration awards. The first method is its most basic method of recognition and enforcement, but from the perspective of current e-commerce development, this method is inefficient. The initial goal of online arbitration is to resolve e-commerce disputes quickly and conveniently. Now it is still mainly focused on e-commerce, especially B2C and domain names. Although there have been correspondingly developed means of autonomous enforcement of online arbitration awards, we should also it can be seen that the current e-commerce has also been widely used in foreign trade, finance, commerce and other fields. Some industries and regions are also using e-commerce. The types of disputes are constantly expanding. In the face of this situation, an autonomous network ruling enforcement system has great limitations in the scope of application, which cannot meet the development needs of the current stage. For this reason, it is also very necessary to establish an efficient network arbitration recognition and enforcement mechanism under the existing legal system, which will undoubtedly better promote the development of network arbitration.

\section{Conclusion}

I believe that from the current point of view, we can start from the following aspects: First, strengthen the cooperation of various network arbitration institutions, and for specific types of network disputes, an implementation mechanism that is widely recognized and adopted can be formed. For example, in the reputation mark promotion mechanism mentioned above, each arbitration institution can formulate and implement the uniform certification, promulgation, and cancellation of the mark, so that online arbitration can be implemented across time and space. The second is to adapt the domestic legislation of various countries in accordance with the provisions of the Convention on matters such as the place of arbitration, arbitration agreement and written form of arbitration awards, and combining the characteristics of online arbitration, various countries can adopt corresponding flexible provisions in order to eliminate and reduce the legal issues on the recognition and enforcement of online arbitration 
awards. The third is to strengthen the exchange of experiences in cyber arbitration legislation and justice between countries, clarify the common standards of consciousness of all countries, and learn from each other's strengths. For example, the development of the New York Convention is closely related to the judicial review system of arbitration awards by the courts of various countries. Conduct discussions to promote the development of international commercial arbitration.

Then, specific clauses on online arbitration have been added to the "Model Law" to clearly stipulate the recognition and enforcement of online arbitration awards. Although the "Model Law" is not compulsory, it has always been the focus of attention of various countries and has provided a reference for national legislation. Therefore, if the "Model Law" is amended, it will speed up the attention and adjustment of various countries to online arbitration to a certain extent regulations, thereby promoting the further development of online arbitration.

\section{Conflicts of Interest}

The author declares no conflicts of interest regarding the publication of this paper.

\section{References}

Akinbote, A. (2009). Arbitration in Africa-The State of Arbitration in Nigeria. Transnational Dispute Management.

Alfred Topper Inc. (New York) v. Edokpolor (1965). 1 All NLR, 292.

Arbitration Act (1996). s 7.

Arbitration and Conciliation Act s.5. (1996).

Berg, A. (1981). The New York Arbitration Convention of 1958: An Overview. Vanderbilt Journal of Transnational Law, 365, 112-137.

Carob Industries Pty Ltd. (In Liquidation) v Simto Pty Ltd. (2000). 23 WAR 515.

China Lawyers Association Website (2016). China's First Internet Arbitration Court Was Unveiled in Beijing. http://www.acla.org.cn/article/page/detailById/11268?from=groupmessage

Chuprunov, I. S. (2012). Chapter I: The Arbitration Agreement and Arbitrability: Effects of Contractual Assignment on an Arbitration Clause-Substantive and Private International Law Perspectives. In C. Klausegger, et al. (Eds.), Austrian Yearbook on International Arbitration (pp. 25-37). Manz'sche Verlags-und Universitätsbuchhandlung.

Cooke, E. (2000). The Modern Law of Estoppel. Oxford University Press. https://doi.org/10.1093/acprof:oso/9780198262220.001.0001

Dallah Real Estate \& Touris Holding Co v Pakistan (2010). UKSC 46 (SC).

Dow Chemical France (1984). The Dow Chemical Company and Others v ISOVER Saint Gobain, Interim Award, ICC Case No. 4131, 23 September 1982. In P. Sanders (Ed.), Yearbook Commercial Arbitration 1984 Volume IX (pp. 131, 136-137). ICCA \& Kluwer Law International.

Gaillard, E., \& Savage, J. (1999). Part 2: Chapter II-Formation of the Arbitration Agreement. In: Fouchard Gaillard Goldman on International Commercial Arbitration (pp. 57-103). Kluwer Law International. 
Hanotiau, B. (2006). Complex Arbitrations: Multiparty, Multicontract, Multi-Issue and Class Actions. Kluwer Law International.

IBA Ethics for International Arbitrators (1987).

IBA Guidelines on Conflicts of Interest in International Arbitration (2004). Approved on 22 May 2004 by the Council of the International Bar Association.

ICC Case No. 1776.

Kamanga, P. (2021). The Power of the Arbitral Tribunal to Determine Its Own Jurisdiction in International Commercial Arbitration. Beijing Law Review, 12, 379-391. https://doi.org/10.4236/blr.2021.122021

Liu, Y. D., \& Chen, L. (2004). Application of Non-State Rules in International Commercial Contracts. OALib Journal, 61, 28-46.

Margulead Ltd v. Exide Technologies (2005). 1 Lloyd's Law Report 324.

Metal Distributors (UK) Ltd v. ZCCM Investment Holdings Plc (2009). 2 Lloyd's Law Reports 37.

Ming, J., \& Sun, Y. Y. (2021). Online International Civil and Commercial Arbitration. https://www.cnki.com.cn/Article/CJFDTotal-CKXX201704121.htm

Mordi, C. (2016). Analysis of the Participation of National Courts in International Commercial Arbitration; Can International Commercial Arbitration Be Effective without a National Court? The Open Journal of Political Science, 6, 95-104. https://doi.org/10.4236/ojps.2016.62009

Park, W. W. (2012). Arbitration of International Business Disputes: Studies in Law and Practice (2nd ed.). Oxford University Press.

Porter v. Magill (2001). UKHL 67.

Primetrade AG v. Ythan Ltd (The Ythan) (2006). 1 All ER (Comm) 157.

Redfern, A., Hunter, M., Blackaby, N., \& Partasides, C. (2015). Law and Practice of International Commercial Arbitration (4th ed.). Sweet \& Maxwell.

Rio Algom Inc. v. Sammi Steel Co. (1991). (CLOUT) (Case 18).12 IBA Ethics for International Arbitrators of 1987.

Zheng, T. M. (2021). People's Court News. https://www.chinacourt.org/article/detail/2019/06/id/4107787.shtml

Zhu, Z. S. (2004). Discussion on Several Legal Issues and Countermeasures of Online Arbitration. Technology and Law, No. 3, 17-35. 